\title{
Qatar as an Oil Emerging Market
}

\author{
Hemin Da \\ School of Management, Shanghai University \\ PO box Room 312, Building W, Shangda Road, NU.99 BaoShao City, Shanghai, China \\ E-mail: johndah@gmail.com
}

Received: April 12, $2011 \quad$ Accepted: May 17, $2011 \quad$ doi:10.5539/ijms.v3n3p141

\begin{abstract}
With a GDP growth rate of 16\% 2009, jumping from 7 billion dollars in 1984 to $\$ 95$ billion 2009 (Qatar statistic authority and world bank 2010), ranking second in per capita income of $\$ 121000$ for 2009 climbing from $20000 \$ 1984$ (world bank 2010), economic freedom world rank 39th of 170 countries, the second in the region 17 countries (2010 IEF), holding some of the world biggest industrial manufacturing in diversified sectors like: oil refinery, liquid natural gas, aluminum, urea, weather cooling systems... Attracting Foreign Investment facilities: independent judiciary, transparent governance ranking the 28th out from 179 countries and stating a legal authorized business take only 6 day compared with world average of 35days (2010 IEF), The GCC member state of Qatar realize an important increase of its economy integration into the global markets, what let the state get hold more confidence of many international partners, and help Qatar to win the bid against USA of 2022 cup organization!

But for which level the indicators of Qatar economy can match more the emerging markets requirements set by world economic known institution?

This study tends to apply, key selected macroeconomic descriptive framework based on indicators and ratios taken from the international comparison program ICP, into the Qatar economic data to test its responding level. We base also on the literature review that defines and measures the emerging markets economics.

This research's findings give a high percentage for the conforming of the Qatar economy indicators to the measurement and standards of emerging markets defined by WTO, WB, IMF and compared by many other world economic high institutions, and open the door to expand the research for new economic classification for world countries, the last one on the issue was done 2005. It may also help clarify some steps in taking decision in developing future strategies for the like-minded countries of the region.
\end{abstract}

Keywords: Oil, Emerging markets, Qatar, GDP

\section{Introduction}

While no generally agreed upon definition for emerging markets exists, the term refers to low-income countries which generally have a rapid pace of economic development and where government policies favor economic liberalization (Hoskisson et al, 2000). These markets not only do some have high economic growth rates but nearly all have high population growth rates (Reynolds, 2006). Some countries can be identified as big emerging markets. According to the World Bank, the five biggest emerging markets are China, India, Indonesia, Brazil and Russia. Other countries that are also considered as emerging markets include Mexico, Argentina, South Africa, Poland, Turkey, and South Korea. THE GCC member state of QATAR, former poor country based beyond pearl fishing, is now the second-highest per capita income in the world, thank to the exploration of large oil and gas fields since seven decades ago, during that period the country pursued many economic reforms to improve the entrepreneurial environment and broaden the national income to other disciplines. But despite the many deferent attempts to diversify the economy, oil and gas still account for $85 \%$ of the state exports revenues and $60 \%$ of the GDP (2010 index of economic freedom). Qatar also suffers of high inflation rates $15.1 \% 2008$, lack of water and agricultural areas, high rate emigration, where foreigners take $60 \%$ of the total population, and the region instability.

\subsection{Hypotheses and Methodology}

This study tends to test and analyze the following two hypotheses:

1.1.1 What are the emerging markets? And are there any common measuring standards for that? That will be 
detailed in the first part of this paper.

1.1.2 The comparison of key economic indicators of the state of Qatar for the emerging markets measuring standards, stated above, to test for how much level Qatar rebooting economy response to the issue.

The methodology is to test and compare in the second part of the study the different sectors of the economy of the state Qatar according to the emerging markets known economic indicators like:

\subsubsection{High growth rates: National income growth, GDP per capita growth and GDP Per Capita}

\subsubsection{Consumer Price Index}

1.1.2.3 Diversification policies: National economic drivers and major reforms policies.

1.1.2.4 Financial sectors and FDI

1.1.2.5 Infrastructure development: roads air transport, internet, Education Literacy rates, Health service covering, Modern industry, Tourism and security.

1.1.2.6 Challenges and future implication: High level of risk and extremely volatile, Population, Region instability, Oil resources dry up.

We test here the economic data for the country according to those indicators and the results will be analyzed in tables and charts and compared with the requirements of emerging markets economies, then we will show out our results that may give new approaches for integrating new economies to the developed and emerging markets, this topic will also open the issue to more researchers for new economic qualifications measurements of other high income countries.

This study is divided into two parts: the first one is devoted to review the literature dealing with identification and specification of emerging markets and their economic indicators, the second is the analyzing part, in which we compare the calculated ratios of Qatar economy and comparing the tables and charts with the standards shown in the first chapter, then concluding with our researches findings and appendix.

\section{Literature Review}

There is some debate in the literatures as to how to define emerging market economies and therefore which countries should be included in any list of EMCs. Emerging markets are nations with social or business activity in the process of rapid growth and industrialization and are restructuring their economies along market-oriented lines and offer a wealth of opportunities in trade, technology transfers, infrastructure and foreign direct investment. (CHUAN LI 2008). Currently, According to The Economist, there are 28 emerging markets in the world, with the economies of China, Brazil and India considered being the largest. US Department of Commerce estimates that over 75 percent of the expected growth in the world trade over the next two decades will come from the more than 130 developing and newly industrialized countries; a small core of these countries will account for more than half of that growth. Commerce researcher also predict that imports to the countries identified as big emerging markets, with half of the world's population and accounting for 25 percent of the industrialized world's GDP today, will by 2010 be 50 percent of that of the industrialized world (Cateora et al, 2006). World Bank has estimated that if current trend continue, by 2020 the Chinese economy could be larger than that of the United States, while the economy of India will approach that of Germany (Economist, 1994).

2.1 Many researches determine that emerging markets stand out due to a number of major characteristics. Certain of these may well apply to other markets as well, but an emerging market generally carries a large number of these features. The main characteristics of big emerging markets that we can summarize as follows:

2.1.1 High growth rate: Emerging markets generally enjoy high growth rates which are often perceived as attractive by investors, although some countries usually described as emerging do have even shrinking economies (Arnold et al, 1998). According to Bridgewater (et al, 2002), emerging markets, such as China, which had the fastest growing, and India, the second fastest growing GDP in the world, represented attractive investment opportunities. That is to say, they are the world's fastest growing economies.

2.1.2 High level of risk and extremely volatile: The second feature of emerging markets, beyond the opportunity they represent for business growth and high returns, is that they entail greater risk that do mature markets. In other words, the strong growth potential of many emerging market economies is accompanied by volatility and high risks (Hitt et al, 2000).

Although market potential in emerging markets is high, this may be realized only in the long term, but in the short term, international entrants face high levels of uncertainty and turbulent market conditions (Bridgewater et al, 2002). In brief, emerging markets are difficult places to do business. There are often complex regulations and 
difficult bureaucracies. Information is scare and enforcing contracts takes time. To put it more simply, they entail volatility and risk.

2.1.3 High population: The market potential of these big markets in terms of population size is immense. As mentioned before, these countries constitute approximately $75 \%$ of the global population. For instance, China's overall population exceeds 1.3 billion, about one-fifth of the world's population.

2.1.4 Regional economic drivers and major political importance: Big emerging markets are regional economic powerhouses with large populations, large resource bases, and large markets. Their economic success will spur development in the countries around them; but if they experience an economic crisis, they can bring their neighbors down with them. Within their regions, they have also major political importance. Furthermore, they are critical participants in the world's major political, economic, and social affairs. They are seeking a larger voice in international politics and a bigger slice of the global economic pie.

2.1.5 Have undertaken significant programs of economic reform: Emerging markets have embarked on economic development and reform programs, and have begun to open up their markets and emerge onto the global scene. They are characterized as transitional, meaning they are in the process of moving form a closed to an open market economy while building accountability within the system. That is to say, they are transitional societies that are undertaking domestic economic and political reforms. They adopt open door policies to replace their traditional state interventionist policies that failed to produce sustainable economic growth.

2.1.6 Large markets: The unmet needs of the emerging or developing world represent huge potential markets (Kotler et al, 2005). Many of these countries lack modern infrastructure, much of the expected growth will be in industrial sectors such as information technology, environmental technology, transportation, energy technology, healthcare technology, and financial services (Cateora et al, 2006).In brief, they represent considerable markets for a wide range of products, and there is no doubt that they will become more significant buyers of goods and services than industrialized countries.

2.1.7 Others: Other characteristics of big emerging markets are as follows: they are all physically large, and they will engender further expansion in neighboring markets as they grow (Cateora et al, 2006).

2.2 In other words there are four major characteristics. First, they are regional economic powerhouses with large populations, large resource bases, and large markets. Their economic success will spur development in the countries around them; but if they experience an economic crisis, they can bring their neighbors down with them.

Second, they are transitional societies that are undertaking domestic economic and political reforms. They adopt open door policies to replace their traditional state interventionist policies that failed to produce sustainable economic growth.

Third, they are the world's fastest growing economies, contributing to a great deal of the world's explosive growth of trade. By 2020, the five biggest emerging markets' share of world output will double to 16.1 percent from 7.8 percent in 1992, IFD UNIV IOWA. They will also become more significant buyers of goods and services than industrialized countries.

Fourth, they are critical participants in the world's major political, economic, and social affairs. They are seeking a larger voice in international politics and a bigger slice of the global economic pie.

Anton Korinek has stated in (emergingmarket.org) that Emerging market policymakers can break the boom and bust cycle of capital flows, says economist The solution includes punitive taxes on dollar debt, short-term portfolio inflows and the stock of foreign capital - as well as a ban on derivatives. Ousmène Mandeng writes at Ashmore Investment Management. "The G20 should establish a facility to unwind unwanted holdings of dollar-denominated international reserves in order to depreciate the greenback and internationalize emerging market currencies"(emergingmarket.org).

2.3 According to Qatar nation bank annual report 2009, the non-oil and gas sector will play even a bigger role in the GDP as some major initiatives that helped diversify Qatar's economy came to fruition. QNB add also that the State economy dependency to oil-gas revenue will to less the $50 \%$ by 2020 . And according to the Bloomberg and IMF Report for 2010, the Qatar's gross domestic product would grow by 18.5 percent this year 2010 as gas exports increase, leaving the economy at risk of overheating in the medium term, the International Monetary Fund said. The country should have "positive" economic prospects in the medium term, with continuing strong growth, moderate inflation and a fiscal and current account surplus in 2010. The country is spending $\$ 100$ billion on projects to build up its infrastructure and raise its annual LNG export capacity to 77 million tons this year from 54 million, according to the same sources. 
But still there some greatest problems facing all of Qatar's economic sectors is the dependence on oil revenue and the adverse impact of the fluctuation of oil prices on the country's investment climate and fiscal deficit. Lower oil prices generally mean lower revenue for the government. Reduced government revenues in turn translate into lower government spending on economic projects, a situation that brings about an overall slowdown in the economy.

\section{Analyzing and Comparing Qatar Economic Data to EMCs}

We test here the data of Qatari's economy according to the following indicators we will compare in each section with selected emerging markets countries and try to describe our findings in tables and drafts:

\subsection{High Growth Rates:}

\subsubsection{National Income Growth}

Data, which are in current local currency, show Qatar as one of the wealthiest countries in the world, by dividing the global national income on population. We see from the draft 1 the changes in GNI between 1970 and 1997 (only provided data) where the curb was almost taking an upward direction.

\subsubsection{GDP High Growth Rates}

Qatar's economy realize some GDP high growth rate thanks to highly dependent on oil and gas extraction which accounts for more than $50 \%$ of GDP, $85 \%$ of export earnings, and $70 \%$ of government revenues (According to the CIA World Factbook for 2001).

You see in the Table1 and Drafts 2 and 3 that the GDP take similar curb for both Qatar and selected EMCs at least in the same period from 2001 to 2009.

The draft 3 shows the gross domestic product growth in the current prices calculated in USD billions for several emerging markets. Currently, According to the Economist, there are 28 emerging markets in the world, with the economies of China, Brazil and India considered being the largest.

\subsubsection{GDP per Capita Growth}

It is calculated without making deductions for depreciation of fabricated assets or for depletion and degradation of natural resources. Data are in current U.S. dollars.

The drafts 4 and 5 show more quick growth for GDP Per Capita in Qatar then different emerging countries.

\subsection{Diversification Policies: National Economic Drivers and Major Reforms Policies.}

Qatar has moved to diversify its sources of income by developing non hydrocarbon sectors over the last ten years, to reduce the dependency on its main economic pillar oil incomes. By basing on Qatar comparative advantages in defend sectors. The non-oil manufacturing sector, accounted for only 8.8 percent, according to the EIU 1996. Agriculture is an insignificant contributor to the economy, accounting for roughly 1 percent of GDP. After 2001 the country has pursued many diversifications reforms to expand the incomes resources. They have inaugurated leading manufacturing and construction enterprises in the world; its liquefied natural gas (LNG) industry and expanding its industrial bas. Qatar Investment Authority (QIA) was established in 2005 as the country's sovereign wealth fund (SWF) to ensure its economic health long after hydrocarbons resources are gone and it has been estimated that their funds could have as much as $\$ 8 \operatorname{trn}$ in resources by 2015. (QATAR OUTLOOK, 2010). QAFCO, QAPCO, QASCO, QATALU and these projects realize high growth wages and estimated to cover more the $50 \%$ of the GDP in the few next years. The hydrocarbon annual growth rate in GDP higher still higher the other sectors of 2.3\% but according to Qatar 2030' vision report the case will verse in few year and the non hydrocarbon projects will take more quick growth rate by 1.3 in GDP more than oil participation. And according to the Central bank report on middle 2010, Consumer prices in the state which has experienced deflationary pressures are expected to rise 3 percent next year versus 2 percent deflation in 2010 . The emirate saw deflation in 2010, but will have a rebound in prices next year because of developments in the housing sector," the QNB said.

3.2.1 Financial sectors and FDI Healthy financial institutions especially banks, is a crucial prerequisite for financial stability. The largest number of crises still arise, be it in emerging market economies or industrial countries, from financial institutions overextending themselves when times seem good and then retrenching violently afterwards. The relentless pursuit of shareholder value, without this crucial adjustment, could prove a very dangerous strategy. The establishment of Qatar Financial Centre, the high degree of ease opening a business in Doha, the government transparency and other initiatives being undertaken will contribute to further economic diversification. The draft 6 shows the degree of ease doing business in selected EMCs, in Qatar only 6days (2010 
IEF).

\subsubsection{Infrastructure Development:}

Qatar has several big airports. Doha International Airport is the most famous one. Doha is served by more than 30 airlines. Qatar has three ports and harbors namely Halul Island, Doha, and Umm Sa'id. Qatar comprises of excellent networks of primary and secondary roads, which links Doha, the capital of Qatar with all the major areas across the country. About $95 \%$ of roads in the state are paved according to WB statistics 2010 . For the other selected emerging markets countries you can see the draft number 7 .

\subsubsection{Health expenditure}

Total health expenditure is 2003 is 1388.2315 and 2007 is 2402.91063 (current US\$ WB Statistics by countries 2010) It covers the provision of health services (preventive and curative), family planning activities, nutrition activities, and emergency aid designated for health but does not include provision of water and sanitation. Draft 8 show the sanitation covering in selected EMCs and Qatar seem to be among the best in sanitary covering.

\subsubsection{Tourism}

International Tourism, expenditures (current US\$) 1999 is 320000000 and 2006 to 3751000000 (WB2010) and expected to receive 7 million tourist for football world cup in next decade.

\subsubsection{Literacy Rates}

According to Data from WB Statistics by countries 2010, the literacy rate, youth who can, with understanding, read and write a short, simple statement on their everyday life. Total (95\% of people ages 15-24 year 2004) and public spending on education, total (1\% of GDP 1975) increased to $3.3 \%$ of GDP in 2005. These rates are the best among all the selected EMCs for this study.

\subsection{Modern Industry}

Qatar has inaugurated some leading modern industries in the world. The oldest of the Qatar industrial companies is QAFCO. Established in 1969, its inception marked the first significant step in the long road of Qatar's industrial diversification program. Its first plant was inaugurated 5 years later, in 1973. Following this, in 1974, both QAPCO and Qatar Steel were incorporated. Qatar Steel commenced production in 1978, with QAPCO starting 3 years later, in 1981. QAFAC, was incorporated in 1991, with commercial operations beginning in 1999. In April 2003, Qatar Petroleum underwent a re-organization whereby it assumed control of Qatar Steel, and also transferred all of its interests in the companies to the recently-formed, Industries Qatar.

After an Initial Public Offering ("IPO") later that year, IQ was successfully listed on the Doha Securities Market ("DSM"). Qatar Intermediate Industries Holding Company Limited (Qatar Holding) is a fully owned affiliate of Qatar Petroleum. It was established by an Emiri decree on 29th December of 2005, Qatar Holding was established to encourage dynamic, market-oriented, local-international pa Qatar Petroleum:

Qatar Petroleum is a wholly government owned and operated company and controls, often via its subsidiaries, all oil and gas activities in Qatar, and is the third largest company in the world in terms of oil and gas reserves. Subsidiaries include Qatar Petrochemical Company, Qatar Fertilizer Company, Qatar Liquefied Gas Company (Qatar Gas), Qatar Chemical Company and Ras Gas. Which produces 10\% of the world's helium? Owned and operated by Qatar Petroleum and Exxon Mobil.

QATALU is one of the world biggest aluminums profile factories. Other leading projects like football stadium cooling system and boats industry are under construction.

\section{Results Discussion}

We summarize here what analyzed in the second part according to the measurements and standards we defined in the first part of this paper and that done by calculating an average percentage for each country in the study those already known as EMCs and Qatar which get a high percentage. To organize that, we draw a comparison's table as you see in Table 3:

The average percentage based on data's tables and drafts data discussed and analyzed in part 2 .

This percentage was calculated by taking an average of each factor analyzed in second chapter during last 10years and specifying a general average for each country. It gave a high level of strength and durability if the percentage tends $100 \%$ and vice-versa when it tends to $0 \%$.

This descriptive approach give Qatar economy some high percentage of strength and durability, but shows also that there is huge challenges that should taken in consideration by policy makers in Qatar and like-wise oil 
dependent economies. If Qatar can maintain political stability and succeed with their structural reforms, their future is promising. In their effort to prove their market economy and to ensure sustainable development, other challenge that come from fundamental problems associated with their traditional economic systems which should more adapt to the international requirements and give more business freedom, transparency and financial sophisticated strategies. Another serious problem that Qatar should take in considerations have to confront is controlling corruption, which distorts the business environment and impedes the development process.

An even more challenging task for Qatar and all EMCs are to undertake structural reforms with their financial system, legal system, and political system, so as to guarantee a disciplined and stable economy that is relatively free of political disturbances and interference.

The market economy requires the Emirate to redefine the role of the government in the development process and to reduce the government's undue intervention. The past track record of many developing countries also demonstrates their inability to well manage and efficiently operate the flowing funds to support economic healthy growth. The EMCs "Qatar" have to establish the preconditions of a market economy and create a business climate that meets the expectations of foreign investors. This change in financing sources thus became another factor leading to the rise of its emerging economy. Then the EMCs will be a key factor in the future growth of world trade and global financial stability, and they will become critical players in global politics.

They have a huge untapped potential to undertake those domestic reforms to support sustainable economic growth to face the crucial future implications of High level of risk and extremely volatility, demography bombs, Region instability, Oil resources dry up.

\section{Conclusion}

This study tried to apply, key selected macroeconomic descriptive framework based on indicators and ratios taken from the international comparison program ICP, into the Qatar economic data to test its responding level. We based also on the literature review that defines and measures the emerging markets economics.

This research' findings highlighted a high percentage for the conforming of the Qatar economy indicators to the measurement and standards of emerging markets defined by WTO, WB, IMF and compared by many other world economic high institutions It may also help clarify some steps in taking decision in developing future strategies for the like-minded countries of the region.

\section{References}

Arnold, D. J., and Quelch, J. A. (1998). New Strategies in Emerging Markets. Sloan Management Reviews, Fall, p.7-20.

Bridgewater, S, and Egan, C. (2002). International Marketing Relationships. Palgrave, p.231.

Cateora, P. R., and Ghauri, P. N. (2006). International Marketing, European Edition, McGraw-Hill, p.250-273.

Economist (1994). War of the Words. A Survey of the Global Economy, October 1, p.3-4.

Hitt, M. A., Dacin, T. M., Levitas, E., Arregle, J., and Borza, A. (2000). Partner Selection in Emerging and Developed Market Contexts.

Hoskisson, R. E, Eden, L., Lau, C. M., and Wright, M. (2000). Academey of Management Journal, 43(3): p.267-294.

Kotler, P., and Keller, K. L. (2005). Marketing Management, 12th Edition, Prentice Hall, p.668-675.

Resource-Based and Organizational Learning Perspectives, Academy of Management Journal, 43 (3): p. 449-467

Reynolds, P. (2006). Lecture Notes.

Table 1 . Shows the how the national economy doubled many tine in the last three decades

\begin{tabular}{|l|c|c|}
\hline year & 1984 & 2009 \\
\hline GDP (Current Prices, US Dollars) & US\$ 6.704 Billion & US\$ 83.91 Billion \\
\hline $\begin{array}{l}\text { GDP Per Capita } \\
\text { (Current Prices, USDollars) }\end{array}$ & US $\$ 20,951.24$ & US\$ 68,871.71 \\
\hline GDP Share of World Total (PPP) & $0.079 \%$ & $0.15 \%$ \\
\hline
\end{tabular}


Table 2. According Latest release from the Labour Force Survey (Canada Statistics 2010-12-05)

\begin{tabular}{|l|l|}
\hline Country & Unemployment 2010 \\
\hline Brazil & $5.70 \%$ \\
\hline China & $4.10 \%$ \\
\hline India & $4.50 \%$ \\
\hline Indonesia & $7.14 \%$ \\
\hline Malaysia & $3.20 \%$ \\
\hline Mexico & $5.50 \%$ \\
\hline Qatar & $0.60 \%$ \\
\hline Thailand & $1.5 \%$ \\
\hline Turkish & $6 \%$ \\
\hline
\end{tabular}

Table 3. An average explain the strength and durability of the emerging economy studied above

\begin{tabular}{|l|l|}
\hline Country & The strength of the economy \\
\hline China & $92 \%$ \\
\hline India & $85 \%$ \\
\hline Brazil & $79 \%$ \\
\hline Turkish & $75 \%$ \\
\hline Mexico & $69 \%$ \\
\hline Qatar & $68 \%$ \\
\hline Malaysia & $66 \%$ \\
\hline Thailand & $65 \%$ \\
\hline Indonesia & $62 \%$ \\
\hline
\end{tabular}

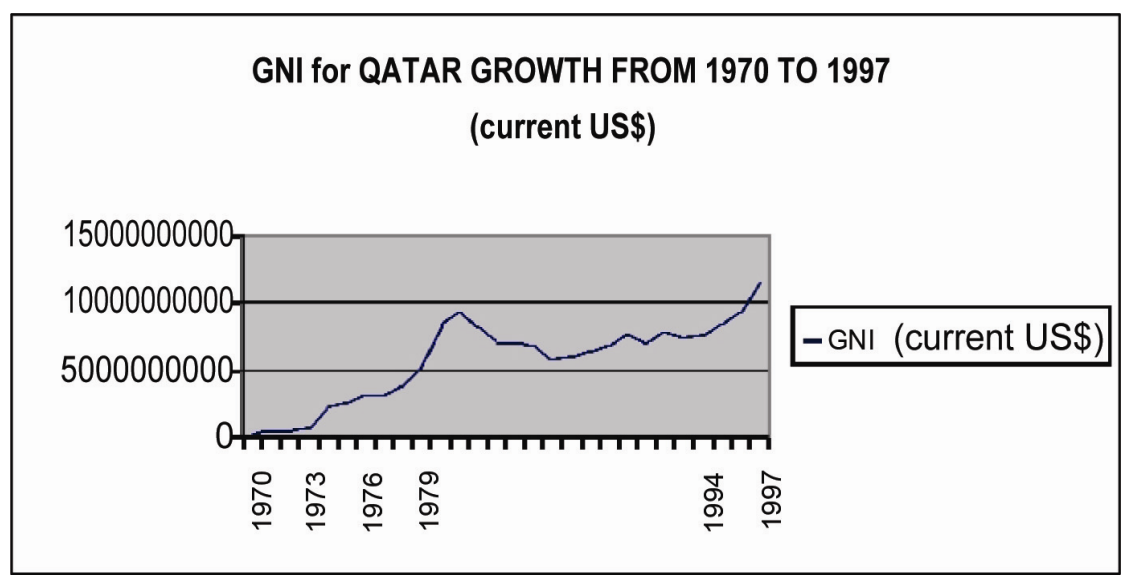

Draft 1. Qatar GNI Growth data from WB IMF1970-1997 


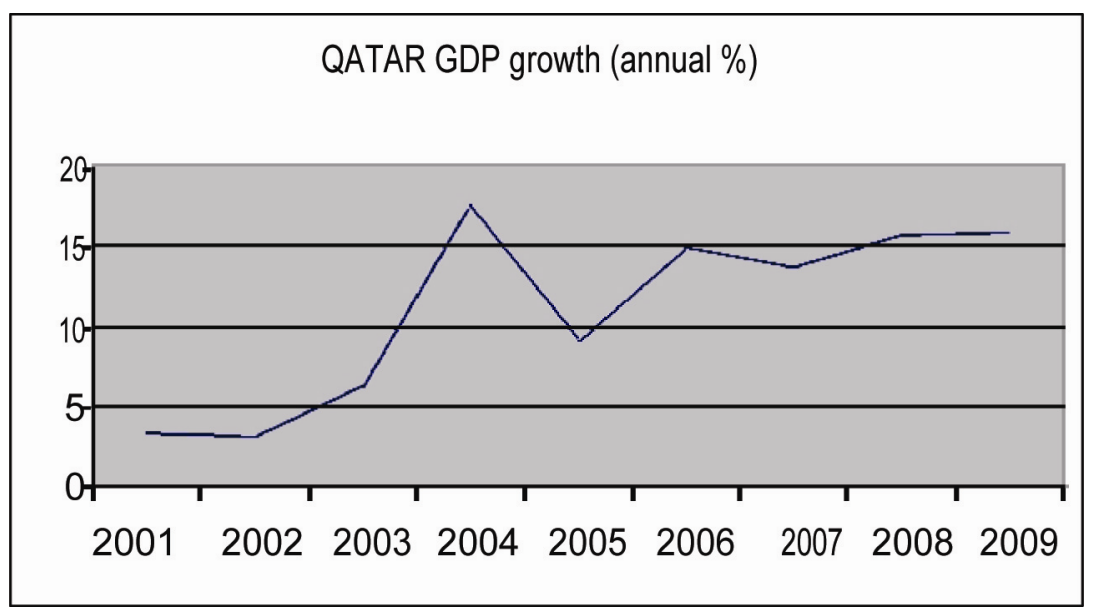

Draft 2. Qatar GDP growth rate of at USD current prices 2001-2009 data IMF WB

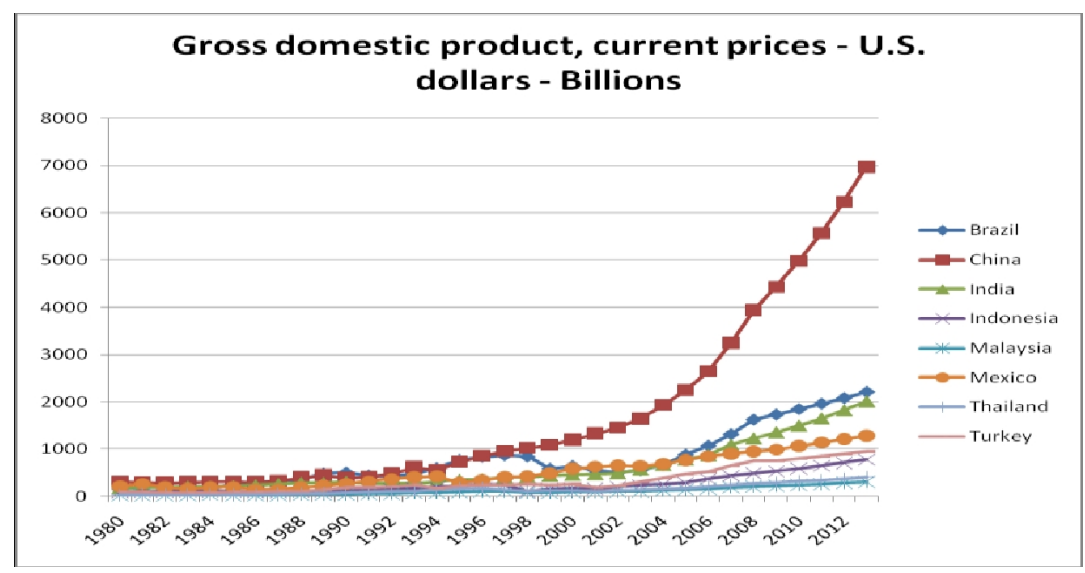

Draft 3. GDP Growth at current prices for selected EMCs Data from IMF WB and economist

You see in the drafts 2and 3 that the GDP take similar curb for both qatar and selected EMCs at least in the same period from 2001 to 2009 .

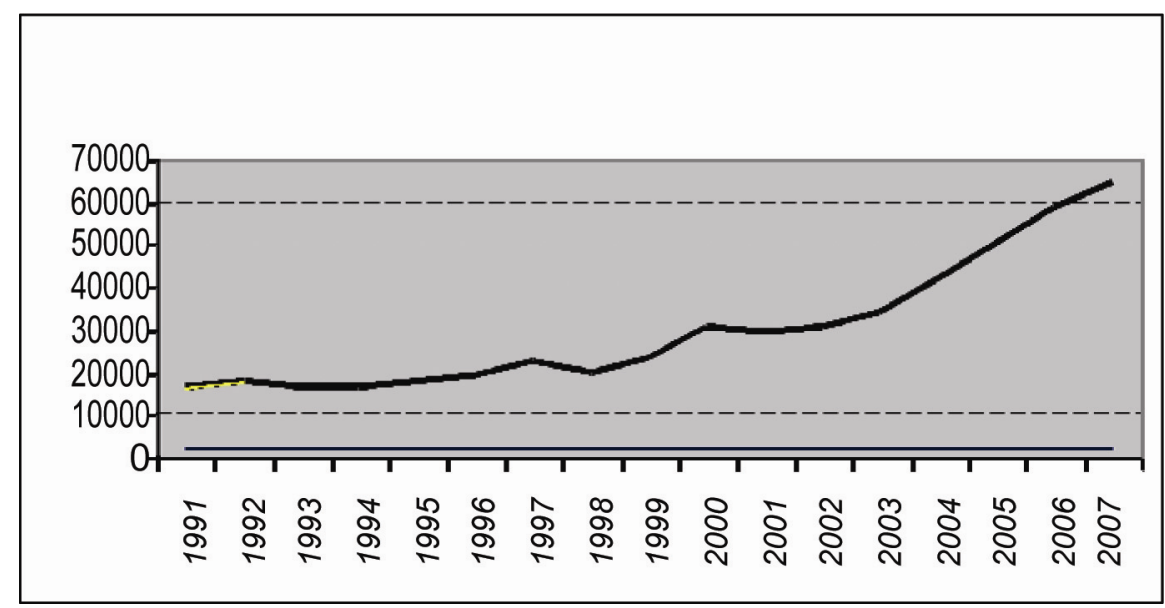

Draft 4. GDP per capita quick growth for qatar (1991-2007 IMF WB) 


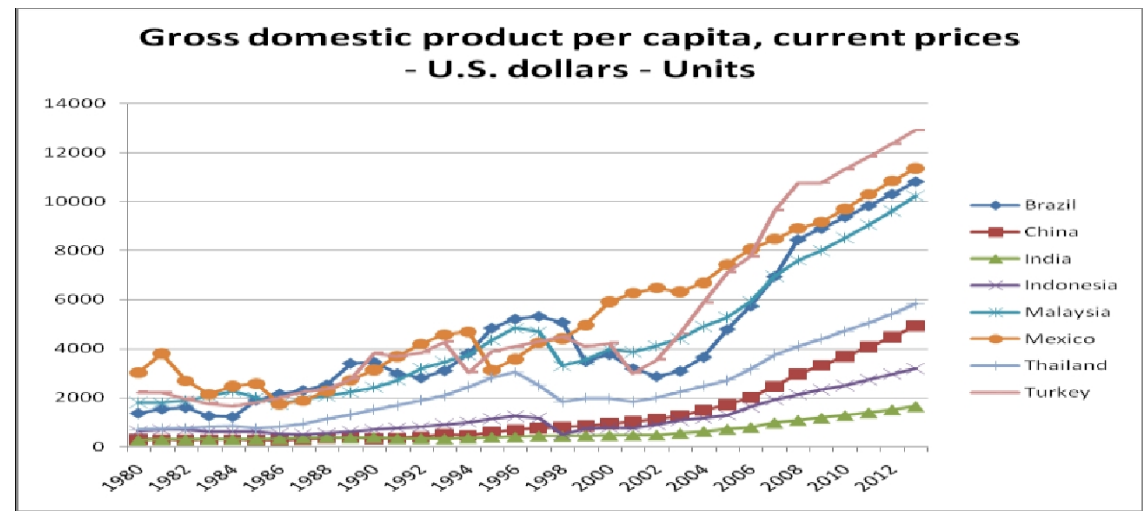

Draft 5. GDP per capita for selected EMCs Data from IMF WB and economist

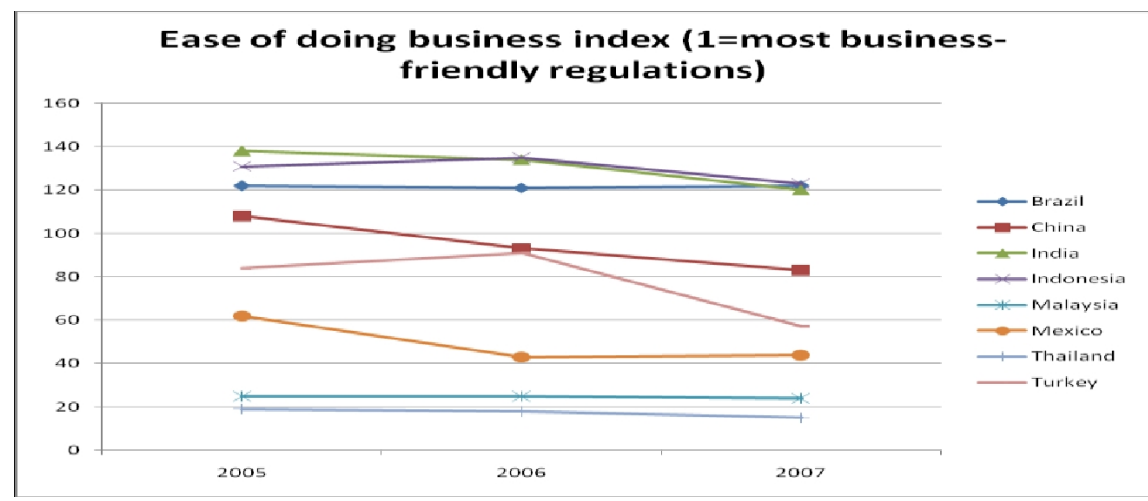

Draft 6. The degree of ease doing business in selected EMCs, in Qatar only 6days. (2010 IEF)

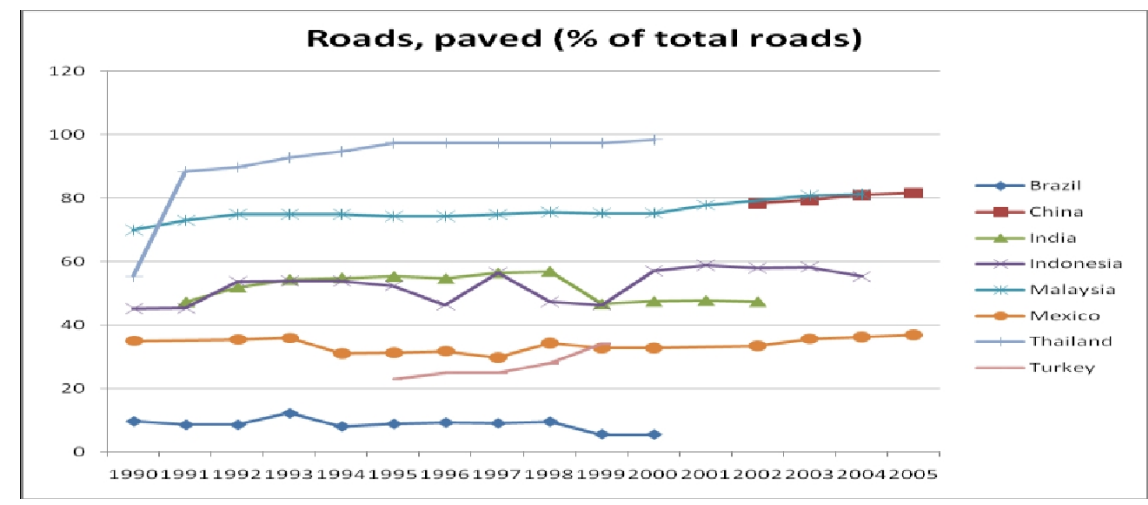

Draft 7. Paved Roads in selected EMCs, in Qatar 95\% of roads are paved 


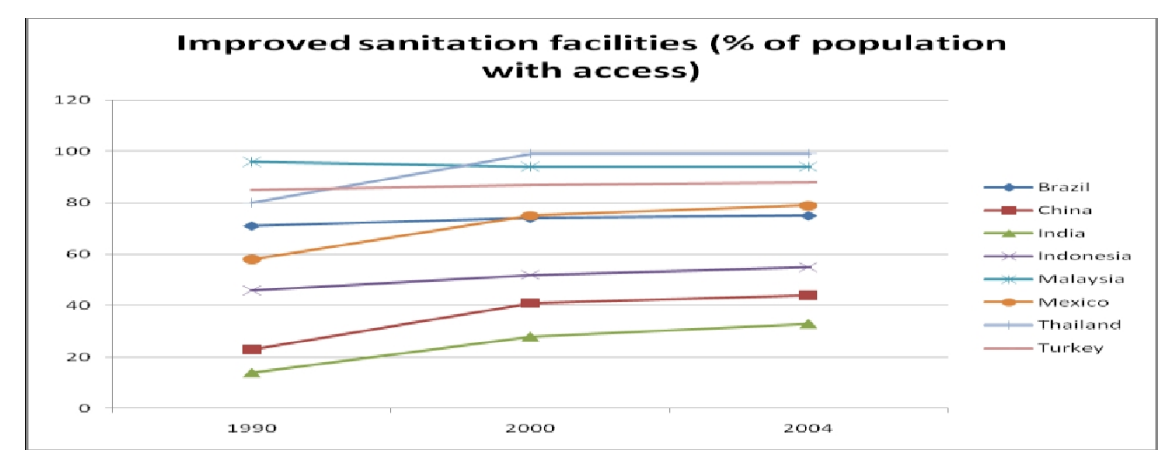

Draft 8. Data are in current U.S. dollars. Note: The latest updates on these data are accessible in WHO's National Health Accounts (NHA) website ( http://www.who.int/nha/en/)

DATA SOURCES:

WORLD BAMNK STATISTIC DATA WEBSITE

IMF DATA BY COUNTRY

WORLD TRADE ORGANIZATION STATISTICS

ECONOMIST INTELIGENCE UNIT,

LIBRARY OF CONGRESS

QATAR OFFICIAL STATISTIC DATABASE

QATAR CENTRAL BANK

2010 INDEX OF ECONOMY FREEDOM

ARAB MONETARY FUND

EMERGING COUNTRIES FORUMS

BBC OVERVIEWS, CIA LIBRARY

http://www.emergingmarkets.com/

http://www.emergingmarketsforum.org/papers/ 